\title{
Amyloid Beta A4 Precursor Protein- Binding Family A Member 2
}

National Cancer Institute

\section{Source}

National Cancer Institute. Amyloid Beta A4 Precursor Protein-Binding Family A Member

2. NCl Thesaurus. Code C104847.

Amyloid beta A4 precursor protein-binding family A member 2 (749 aa, $\sim 83 \mathrm{kDa}$ ) is encoded by the human APBA2 gene. This protein plays a role in the modulation of both vesicle transport and proteolytic processing of amyloid beta A4 precursor protein. 